\title{
Umwelt Transitions: Uexküll and Environmental Change
}

\author{
Morten Tønnessen
}

Received: 1 December 2007 / Accepted: 15 October 2008 /

Published online: 7 January 2009

(C) Springer Science + Business Media B.V. 2008

\begin{abstract}
What role does environmental change play in Jakob von Uexküll's thought? And what role can it play in a up-to-date Uexküllian framework? Admittedly, in hindsight it appears that the Umwelt theory suffers from its reliance on Uexküll's false premise that the environment (including its mixture of species) is generally stable. In this article, the Umwelt theory of Uexküll is reviewed in light of modern findings related to environmental change, especially from macroevolution. Uexküll's thought is interpreted as a distinctive theory of phenomenology - an 'Uexküllian phenomenology' — characterized by an assumption of the (in the realm of life) universal existence of a genuine first person perspective, i.e., of experienced worlds. It is suggested that acknowledging this distinctiveness is critical for ecophenomenology as well as for biosemiotics; the latter of which can only thus thrive as a true 'semiotics of being', rather than a mere 'semiotics of functioning'.
\end{abstract}

Keywords Balance of nature $\cdot$ Biodiversity $\cdot$ Ecological crisis $\cdot$ Ecosemiotics

Macroevolution $\cdot$ Phenomenology $\cdot$ Umwelt

In [his] static idea, a series of problems in Uexküll's position becomes clear. The perfect fit between animal and Umwelt of course requires the static nature of the latter. In a changing world, no perfect fit may a priori be assumed, but rather a continuum of differing degrees of fitting.

Frederik Stjernfelt (2001: 86)

Jakob von Uexküll (1864-1944) held a static view of nature in which harmony and order defined the ecological situation. Today we know that most environments, if not all, undergo cycles of change. The alleged 'balance of nature' now appears to be a temporary state, at best. Though it might be unreasonable to expect Uexküll to

\footnotetext{
M. Tønnessen $(\bowtie)$

Department of Semiotics, Institute of Philosophy and Semiotics, University of Tartu,

Tiigi 78, 50410 Tartu, Estonia

e-mail: mortentoennessen@gmail.com
} 
have foreseen the massive and rapid environmental changes taking place in the contemporary world, it is evident that his concepts on some points are untimely. In hindsight it appears that the Umwelt theory suffers from its reliance on Uexküll's false premise that the environment (including its mixture of species) is generally stable.

One of the great innovations of Uexküll's Umwelt theory was to investigate the life processes from the point of view of the specimen, i.e., the individual living being, regarded as an organism endowed with subjectivity. From this perspective it followed-though it was by no means a necessity - a certain methodological ahistoricity, or neglect of the historical dimension of the life processes. The time frame he operated with was principally the subjectively experienced time of the specimen under scrutiny. As Fraser (2001) points out, time in Uexküll's thought is mainly momentary. Indispensable as the momentary perspective might be for any biology worthy of the name 'subjective biology', it has become obvious, in our time of environmental change, that much larger time scales as well deserve our attention - extending all the way back to the origin of life.

The ecological crisis has rightfully been characterized as a crisis of epistemology and a crisis of communication. In "Umwelt ethics" (Tønnessen 2003) I defined it as an ontological crisis, i.e., a crisis of the known phenomenal world characterized by a sudden, significant loss of phenomenal (implicitly also behavioural) diversity. As Leakey and Lewin state (1996: 7) "it is now possible to look at the pattern of mass extinctions in the fossil record and see these events as a major creative force in shaping life's flow". This calls for an investigation into the historicity of phenomena in the realm of biology.

While for Darwin evolution tended generally towards improvement, for Uexküll life was already from the start fitted to perfection. For us contemporaries it is becoming clear that perfection, in ecological terms, is a fragile state. "Every Umwelt of a normal animal", according to von Uexküll (2001: 120)_alluding to his familiar musical metaphor - "is a faultless composition of nature-you only have to understand how to look for its theme and its notes". In our world of massive ecological degradation, not least in form of habitat loss, we cannot but observe how many beings today face increasing difficulties performing their all-to-natural Uexküllian duets - obstructed, in effect, by the expansion of the human habitat. Their struggle to maintain their ways of life amounts to a struggle for survival of a kind that neither Uexküll nor Darwin foresaw.

This piece of work can be labelled ecosemiotics. ${ }^{1}$ While Winfried Nöth (1998; cf. 1996) defines ecosemiotics as the study of the semiotic interrelations between organisms and their environment, according to Kalevi Kull (1998: 350) it is "the semiotics of the relationships between nature and culture". In the context of this article, ecosemiotics can be understood as the semiotic study of ecological relations and complexity in general, and human-nature relations in particular; thus enveloping, in the broader scheme, topics of cultural semiotics as well as general biosemiotics.

I will set out by defining an 'Umwelt transition' - an Uexküllian concept of environmental change - and review a few modern findings about the volatile nature of ecosystems. I then examine Uexküll's concept of Bauplan in light of the Cambrian explosion and the concept of 'phylum', and compare my Uexküllian

\footnotetext{
${ }^{1}$ Curiously, ecosemiotics is left out of Thomas Sebeok's list of branches of biosemiotics in his programmatic essay 'Biosemiotics: Its roots, proliferation, and prospects' (2001: 75).
} 
concept of 'ontological niche' (based on Uexküll's concept 'contrapuntal relation') with Jesper Hoffmeyer's concept of 'semiotic niche'. Categorical perception is recognized - as Frederik Stjernfelt has suggested — as a semiotic notion. Thereafter I depict an Uexküllian phenomenology, by reviewing it in relation to, among others, Kant, Merleau-Ponty, Abram and the so-called eco-phenomenology. I will argue that biosemiotic notions of 'subjectivity', 'autonomy' etc., only retain their meaning on the metaphysical assumption that they ultimately refer to an existential realm.

\section{Toward a Phenomenology of Environmental Change}

Nature is a complex structure and holistic system which permanently reshapes and renews itself.

Jakob von Uexküll (1922: 317)

Whatever the nature of the ecological crisis might be asserted to be, the keyword 'environmental change' seems unavoidable in answering that question. In this paper I will start developing a concept of Umwelt transition, i.e., an Uexküllian notion of environmental change. An Umwelt transition - so I suggest-can tentatively be defined as a lasting, systematic change, within the life cycle of a being, considered from an ontogenetic (individual), phylogenetic (population-, species-) or cultural perspective, from one typical appearance of its Umwelt to another. An Umwelt transition, in other words, can be regular, irregular or a singular, extraordinary event. In the last case we are entitled to talk about historical events. In a similar vein, transitional Umwelten can be taken to refer to Umwelten undergoing an Umwelt transition or Umwelten in so far as they typically go through a certain kind of Umwelt transitions. Whereas the definition of an Umwelt transition makes the concept applicable within psychology (concerning 'life-changing events') as well as within cultural studies and anthropology, my treatment of the subject in this introductory article will be limited to issues of macroevolution, all somehow related to 'environmental change'.

To invoke an environmental crisis is in effect to invoke a certain (adverse) environmental change, in the common, materialist usage of the concept - in other words, a change in the conditions for life. If not before, then at least by inflicting planetary climate change, our current anthropogenic ecological crisis has reached a global scale, thus entitling us to talk about a global Umwelt transition, changing the conditions for life for all or most life forms. Among the forerunners of the current global Umwelt transition we find the five mass extinctions following the Cambrian explosion, known as The Big Five. During these global events, what ruled the day was curtailed and unfulfilled duets of nature or, as we might say, 'dissonances' in the symphony of nature. Characteristic for these devastating ecological events, which in their aftermath gave rise to eras of heightened evolutionary innovation, was that they marked a shift in what life forms were thriving and dominating-with the marginalisation of some and the total exclusion of others. One of the reasons why occurrences of extinction have the potential to accelerate is related to what we could call an ecological domino effect, mirroring ecological interdependence. In Uexküllian terms, contrapuntal relations, or natural 'duets' (i.e., ecological relations) 
always involve counterparts, the crumbling of one part might trigger the crumbling of its counterpart, which might in turn trigger the crumbling of its counterparts, and so on.

Using the term 'global Umwelt transition', one has to keep in mind that in an Uexküllian sense, 'nature', as a global entity, is composed of all individual Umwelten (or phenomenal worlds). This, of course, corresponds to the 'semiosphere' in its postLotmanian sense. Given that what is fatal to one Umwelt might be rejuvenating to another, and that the systemic changes involved in a global ecological event are never evenly distributed, a 'global Umwelt transition' does not entail that the same kind of change appears in all Umwelten. There are, however, global tendencies of changes and shifts in the conditions for life (such as 'generally hotter, most areas heating rapidly', 'practically no sunlight reaching the ground for several months', 'a super-continent formed by the junction of all major continents'), and it is these big-scale tendencies that define, or trigger, the global events.

Caution should also accompany the term 'being'. In my preliminary definition of Umwelt transition, the being undergoing change can be anything from an individual, a population (including a culture) or a species. First, one could note that organic entities lower than that of the organism (such as organs, tissue, cells, and organelles) fall below the chosen threshold - in so far, that is, as systematic changes in endosemiosis taking place at those levels do not give rise to a lasting change at the level of the organism. Second, 'being' is at the lowest level identified with 'individual', though, evidently, the concept of 'individual' is not applicable to all life forms. This term should be comprehended as something akin to a 'carrier of a first person perspective' (be it singular, as in the case of most vertebrates, and unicellular beings; or plural, as in the case of plants, fungi and invertebrate animals). Finally, observing my leap from 'being' to 'nature' (i.e., the global ecosystem), one may well notice that what I am doing is in fact to construct the global in terms of the individual. The individual level, in other words, occupies the centre- the middle ground - of this methodology; at the crossroad, one might say, where the somatic realm encounters the ecological one. Such an approach, which I believe to be in line with Uexküll's thought (as the individual, not the species, serves as his theoretical point of departure), and which stresses subjectivity while at the same time allowing for the complex interconnectedness of the life processes - defining, as we shall see, the organism in terms of its ecological relations - might be labelled an integrated biological individualism.

\section{From 'the Balance of Nature' to 'Environmental Change'}

Though the exact phrase 'the balance of nature' is of fairly recent origin, it expresses an idea about an alleged stability of nature that has a long history. In the words of Leakey and Lewin (1996: 151), it "became a powerful metaphor in ecological and lay circles for a perceived fundamental natural harmony". Conveying a static way of how ecosystems work, it has nowadays been replaced by a notion of dynamic change. Since the death of Jakob von Uexküll in 1944, we have not only come to recategorize the living in five kingdoms, rather than two. One might claim that most of the substantial modern findings within the life sciences concern the historical temporality and the contingency of life. 
One of the ideas Uexküll opposed most vigorously - that living beings passively adapt to their physical environment - might now be in the process of turning into a minority view. An opposing view, that organisms actively modifies and maintains their physical environments, is gaining momentum. We know today, for instance, that the transition from a very low level of oxygen in the atmosphere to a level comparable to that of today-arguably the single most decisive shift in the conditions for life in Earth history, as it also helped to maintain the oceans perpetually - was due, ultimately, to the advent of photosynthetic microorganisms about three billion years ago. Without it, the Earth's present biota would hardly be dominated, as it is, by oxygen-tolerant organisms thriving on the basic contrapuntal relation which photosynthesis forms with respiration. As Jesper Hoffmeyer (2004: 86) notes, "the molecular splitting [plant life] and reassembling [animal life] of water" brilliantly exemplifies how a more complex cycle of events in the physical world (water being constantly split and reassembled) can give rise to growing biodiversity.

In our days, climate change is the single ecological issue that more than any other is causing us to reflect anew on changes in the natural world throughout Earth history. Uexküll could easily have agreed with James Lovelock (2006: 27) that "all life forms have a lower, an upper and an optimum temperature for growth and the same is true for acidity, salinity and the abundance of oxygen in the air and water". What would be new to him would be the finding that throughout Earth history, global temperature has fluctuated substantially, at times rapidly. Scholars have claimed-probably rightfully so - that nothing comparable to the modern global warming has occurred since the transition from the last glacial to the current interglacial - and soon maybe not since the start of the Ecocene, some 55 million years ago. Still, even without any human causation in this case, just 10-20.000 years ago the Amazonian forests were mere scattered fragments. There was no continentwide forest cover during the end of the last ice-age. This is hardly the popular image of the Amazonas - symbolizing, as it still does, an apparently unmovable wilderness.

As part of our newfound recognition of nature's volatility, we now know better than ever before that the existential state of being mortal does not only apply to the individual, but also to species. While mammal species, according to our best guess, demonstrate an average life span of one to a few million years, compared to 5-10 million years for species in general, even invertebrate species don't display an average period of biospheric existence much longer than 10 million years (Sarkar 2005: 139; cf. Leakey and Lewin 1996). Of the 30 billion species estimated to have existed since the Cambrian explosion, some half billion years ago-which admittedly represents a wild guess ${ }^{2}$ - maybe as little as one out of a thousand species are present today. The rest are extinct.

\footnotetext{
${ }^{2}$ This corresponds to a much more reliable estimate of the number of human beings that have ever existedsupposedly around 70 billion people. Remarkably proximate, these estimates represent a ratio of roughly 2 to-1 in favor of human individuals. Based on current estimates of the number of existing species worldwide, we can stipulate, with near certainty, that the number of existing human individuals only surpassed the number of existing species somewhere between 10.000 B.C. and year 1 (for historical estimates of world population, cf. Kremer 1993). Today that ratio is somewhere near the range of 100-1.000 in favor of human individuals.
} 
Life, in other words, is in flux. Ecosystems are not static, but rather cyclical, in part unpredictable and - ceaselessly-developing systems of life. "It lies at the heart of biosemiotics", as Hoffmeyer (2004: 73-74) states, "that indeterminacy is primary, that 'habit taking' or interpretation are real processes in the world". Much of the time nature is, as a matter of fact, chaotic; and random events can be decisive for further developments. I agree with Hoffmeyer (same pages) that Uexküll's work "is still in need of clarification, [at the same time as] the biosemiotic reframing of biological theory, which owes so much to his work [...] can still be fruitfully informed by the work of the pioneer". One clue to a clarification, or further development of Uexküll with regard to nature's volatility is found in Stanley Salthe's remark (2001: 375) that Uexküllian semiosis can be regarded as fundamentally fallible because "it delivers a radically incomplete world view", given that an Umwelt by definition consists of a narrow selection of the potential environmental clues.

\section{On the Forms of Life}

Uexküll has - famously_influenced ethology, the study of animal behaviour, not least through his influence on Konrad Lorenz. "The research program mapped out in [Uexküll's books]", Lorenz (1973: 275-276) admitted, "is pretty nearly identical with that of ethology". Lorenz adopted some of Uexküll's concepts, but dismissed his theoretical base, characterizing it as vitalistic and anti-evolutionist. Whereas some authors (e.g. Stjernfelt 2001) have asserted that Uexküll was anti-evolution, others (e.g. Salthe 2001; Kull 2004) have concluded that he was undeniably antiDarwinian, but not hostile to the idea of evolution as such. As I shall argue later on in this paper, an Uexküllian perspective might actually prove to be enriching within the field of evolutionary theory. For now it will suffice to refer to von Uexküll's dictum (1928: 198) that "each new appearing functional cycle verifies [the appearance of] a new animal species". 3 The functional cycle's species-defining role points to a fundamental ambiguity in that concept, since the aggregate Umwelt of an entire species is also said (1928: 181), in general terms, to be "larger and richer than the Umwelt of each [member of that species]."4 The resulting functional diversity is, according to Uexküll, "the raison d'être of the species" ("der Hauptdaseinsgrund der Art").

I now turn to Uexküll's concept of the Bauplan - the building plan, or (physical and functional) design - of a being. The concept of a body plan was originally developed by Cuviér and Geoffrey Saint-Hilaire, but had already been prefigured by Linné in his idea of classification. In Uexküll's theory, as Brier notes (2001: 785), it is moved into a bio-phenomenological setting, possibly inspired by Leibniz' philosophy. In Umwelt and Innenwelt der Tiere, von Uexküll (1909: 5) states that the Umwelt is essentially a reflection of the Bauplan.

The assumption that the different individuals of a species are more or less well

fitted to their Umwelt is [with no basis in reality]. Each and every individual is

\footnotetext{
3 “Jeder neuauftretende Funktionskreis begründet eine neue Art von Tieren".

4 “[...] größer und reicher [sein] als die Umwelt der einzelnen."
} 
different, according to its varying Bauplan, but perfectly fitted to its Umgebung [physical environment]. [This is because] the Bauplan, to a significant extent, independently provides the Umwelt of the animal. ${ }^{5}$

On the other hand, von Uexküll states (1921: 20) that "the Bauplan of animals [changes] constantly under the influence of the environment, so that oneoverstating the point — can say that a [stimulus] never reaches the same animal two times". 6 Summing up these two seemingly contradictory aspects of the Bauplan, Aldona Pobojewska (2001: 325), one of the most attentive Uexküll scholars, writes that the Bauplan "determines what the living being perceives and how it acts, which elements of its perception and activity are constant, and which ones may change in the course of its life".

In the modern reading of Uexküll, it is often taken for granted that the species is the relevant level of inquiry. This is by no account obvious - higher as well as lower classifications might very well qualify for the use of Uexküllian terms, as long as the physical traits that are indicative of classification really point to related functional, i.e., behavioural qualities, reflected in ecological relations and re-enacted, once again, at the level of phenomena. Take the phylum, the highest taxon of classification, second only to the kingdom, which signifies a group of animals that share the same physical body plan, i.e., a set of anatomical characters that describe the spatial organization of an organism's organs. During the Cambrian explosion, it is conceivable that as many as a hundred animal phyla came into being, of which only 33 exist today - nevertheless representing the full scope of today's variety of fundamental body plans. I see no problem in applying the concept of 'Umwelt' at the level of a phylum - implying, then, that what is described is the common, or more or less alike, features of the Umwelten (or phenomenal worlds) of all beings belonging to a certain phylum (say, the chordates, the phylum to which we belong - characterized by an internal skeleton, a ventral heart and a dorsal nervous system). This can be done in at least two ways, corresponding to describing what I have elsewhere (Tønnessen 2003: 288-289) called 'common-Umwelten' and 'total Umwelten' respectively. While a common-Umwelt can be understood as a particular part of a group of Umwelten belonging to a group of beings that have certain schemata in common, a total Umwelt is to be understood as the sum total of phenomena appearing in the Umwelten of a particular group of beings. Naturally, these entities are abstract, or aggregate phenomenal entities and it is important to keep in mind that, unlike with singular Umwelten, they do not correspond to anything actually experienced in its entirety by any one being.

Such a description of the Umwelt of a phylum, or another high-level category of classification, will typically be a lot vaguer, allowing for more internal phenomenal variety, than the description of a singular Umwelt. But in the case of beings with a high degree of individual variety within a species, any description of their Umwelt, qua species, is deemed to be vague in any case. The degree of vagueness that is

\footnotetext{
5 "Die Behauptung, dass die variierenden Individuen einer Art mehr oder weniger gut ihrer Umwelt angepasst seien, ist völlig aus der Luft gegriffen. Jedes variierende Individuum ist entsprechend seinem veränderten Bauplan anders, aber gleich vollkommen seiner Umgebung angepasst. Denn der Bauplan schafft in weiten Grenzen selbsttätig die Umwelt des Tieres."

6 "Der Bauplan der Tiere [ändert sich] dauernd unter dem Einflusse der Umgebung, so da $\beta$ man mit Übertreibung sagen kann, niemals trifft ein Reiz zum zweiten Male das gleiche Tier.“
} 
necessarily involved further refers to a similar level of abstraction in the phenomenal inquiry. Needless to say, any decent phenomenological analysis (pretending to get 'closer to actual reality') should incorporate 'close-ups' as well as the big picture.

The origin of biodiversity should in my opinion be a major general topic in biosemiotics. Revisiting the concept of the Bauplan, we are now prepared to realign it with the phylum, commonly referred to as a fundamental 'body plan'. The Bauplan concept, as well as the concept of Umwelt, should be considered to be operational throughout the classificatory system, with the same theoretical limitations as mentioned above with regard to the Umwelt concept. Integrating Umwelt theory with modern findings about macro-evolution, we can agree with Leakey and Lewin (1996: 85) that "there are some constraints in possible biological architecture, usually relating to biomechanics ... [but] although there is not an infinity of forms, the Cambrian bestiary almost certainly was just one of many such possible worlds". "The biosphere", in the words of Stuart Kauffman (2000: 145), "may well be kinetically trapped into an evermore astonishingly small region of the entire space of the possible it might have reached". As Hoffmeyer remarks (2004: 89), "having lost a large majority of the options originally available for the evolutionary path, diversification nevertheless has expanded the field of future options by inventing radically new and sophisticated life strategies based on highly developed semiotic competences".

\section{On the Niche of Life}

"The character of the animal's Umwelt", in the words of Jesper Hoffmeyer (1996: 140), "is what defines the spectrum of positions that an animal can occupy in the bio-logical sphere, its semiotic niche". His concept of a 'semiotic niche' is intended to describe "that subset of the local semiosphere which the species must be capable of controlling" in order to thrive (Hoffmeyer 2001: 391). Inspired by that conception, I introduced the concept of an 'ontological niche' in my article 'Umwelt ethics' (Tønnessen 2003). In a natural world of faltering biological diversity, countless beings do not, any longer, master the semiotic niche conditions which according to Hoffmeyer are vital to the success of an organism. It was to accentuate the subjective reality of our current predicament that I named the ecological crisis an 'ontological crisis', and reconceptualised Hoffmeyer's semiotic niche as an ontological niche.

The ontological niche of a being can be defined as the set of contrapuntal relations that it takes part in at a given point of natural history. The ontological niche of a being delimits the 'area' that this being occupies in the phenomenal world. Figuratively, ontological niches would best be represented not as separate slices, but rather as overlapping phenomenal 'fields', where the phenomenal field of any one being overlaps with the fields of all other beings with which it is interacting. Such a figure, or ontological map, would depict the being in its phenomenal relations, i.e., it would portray the being as a creature with a specific phenomenal world where a certain selection of other beings is involved. As we can see, through its ontological niche, the phenomenal world of a being is intertwined with other phenomenal worlds, thus integrating it into the society of phenomenal subjects.

While Hoffmeyer's niche stresses the niche conditions related to semiotic competence, the ontological niche concept stresses the interdependence of the living 
subjects involved. The main difference might be one of emphasis, or perspective. The semiotic niche is of course itself a rephrasing, or remodeling, of the much more established term 'ecological niche', of which there are three concepts among ecologists, all of them externalist. Whereas some Uexküll scholars dismiss any resemblance between ecological niches and the Umwelt concept, Stanley Salthe (2001: 371-372) points to certain similarities between an Umwelt and a Hutchinsonian niche (cf. Hutchinson 1978), which emphasizes differences and, like an Umwelt, can only be scientifically remodeled following detailed examinations. The ontological niche concept, on its hand, should be operable at any level ranging from the individual to (by extrapolation) levels higher than that of the species-but cannot, at any rate, be applied as a timeless, ahistorical conception (momentary, yes, but not unchanging). It, too, is a tool for mapping (i.e., systematic, relationally oriented description) of complex ecological conditions and relations, rather than for prediction of specific events. Or, put another way: The only prediction its use can result in is the vague forecast that ecological disturbances are likely to result if certain ecological relations are not maintained. A crucial question is which ecological relations qualify as vital relations. These can in my reading of Uexküll be defined as vital contrapuntal relations, namely contrapuntal relations that are necessary (rather than contingent) and irreplaceable (as opposed to replaceable). Due to the complexity and historicity of natural systems, however, the distinction between relations that prove to be vital and those who do not can in many cases only be done posthumously, if at all.

In his essay 'Umwelt', John Deely (2001: 129-130) points to how much richer the Umwelt concept is than the materialist concept of an 'environmental niche'.

The concept of environmental niche simply identifies that part of the environment as physical upon which a given biological form mainly depends in deriving the physical aspects of its sustenance. The concept of Umwelt, by contrast, shows us how a given 'environmental niche' is merely the physical part of a larger, objective, not purely physical whole which is, as it were, fully comprehensible only from the perspective of the particular lifeform whose world it is.

Uexküll describes ecological relations as mutual and complementary. "Wherever we look", he claims (1931: 391), "we see ... the complementary matching of pairwise mutually coordinated Umwelten". ${ }^{7}$ Since functional cycles, each representing one action with its associated perception, can be regarded as special cases of contrapuntal relations, the concept of Umwelt is directly related to that of contrapuntal ecological relations. We might say that while the Umwelt represents the behavioral and perceptual repertoire of a living being, being uncovered by experience and therefore potentially only partially known in the Innenwelt of an individual, as Salthe (2001: 366) observes - and a functional cycle an action-directed and alert, momentary Umwelt; a contrapuntal relation subsists between the Umwelt carrier and each of its Umwelt objects - be it animate or inanimate-which it

\footnotetext{
7 "Wohin wir schauen, erblicken wir [...] komplementäre Einpassungen paarweise aufeinander abgestimmter Umwelten".
} 
actively relates to. ${ }^{8}$ The ontological niche concept, therefore, being defined as the set of contrapuntal relations a being takes part in, is an offshoot of the Umwelt concept, representing, as it does, Umwelten, or phenomenal worlds, in their aspect of subjective (i.e., first and/or second person) relations from an objective (i.e., third person) perspective. ${ }^{9}$ A being, defined by the relations in which it takes part, can be framed as an instance of relational being.

Recalling that maybe as little as one out of a thousand species are still around, we cannot but acknowledge that the coming-into-be and breaking-up of ecological relations is a habitual phenomenon in nature. This is due not solely to extinction and speciation, but much more frequently owing to migrations and fluctuating populations. At any rate, the way in which living beings navigate in changing environments is bound to be reflected in a certain plasticity of their relational being. This flexibility, however, has its limits, the encroachment of which results in death, be it for a population or a species.

Having realized that a living being is constituted by its relations, and recognized that the functioning of ecosystems are characterized by waves of integration and disintegration of ecological relations, we can now proceed to another concept of constitutive importance, namely that of 'categorical perception'. Categorical perception, originally a concept from psychology, can be understood as perceiving in terms of categories, i.e., recognizing objects of perception by aligning them to already familiar categories of objects. As Frederik Stjernfelt (2001: 95) has remarked, "a closer analysis of a contemporary version of Uexküll's Umwelt forces us to acknowledge categorical perception as a primitive notion in semiotics", and as a "semiotic piece of formal ontology". In addition to that, Stjernfelt (2001: 90) argues that "the whole Umwelt biosemiotics should be reconstructed in terms of categorical perception".

In Uexküllian terms, we could say that categorical perception is performed whenever an Umwelt carrier, i.e., a being operating in functional cycles, recognizes an object in its Umwelt as belonging to a specific category of objects which makes a difference in its life (e.g., something 'edible', 'threatening'), as allowed for by its Bauplan, i.e., its physical and behavioural constitution. As Stjernfelt remarks (2001: 90), while "it is long since admitted that higher animals perform categorical perception, ... Uexküll's claim that even single cell microorganisms possess functional circles takes categorical perception back to a much more primitive level of biology". The laws of perception, we might say, are subordinate to the constitution of the Umwelt carrier. Performing categorical perception represents the first step in contextualizing phenomena - the first distinction between what is to be ignored and what is to be noticed-contextualizing them, so to say, in relation to the Bauplan. As this concept illustrates - at the most basic level of semiotic competence - perception as such is always normative, i.e., selective, involving acts of interpretation as well as a continuous contextualization of developing events.

\footnotetext{
${ }^{8}$ Reserving the term 'Umwelt' for animals (rather than plants and fungi), one would have to generalize this point by stating that "a contrapuntal relation subsists between the carrier of a phenomenal world and each of its Umwelt objects and/or meaning factors". Meaning factors, such as temperature, humidity or whatever might be relevant for the being in question, are of course of distinctive importance for any being, including animals of all kinds.

${ }^{9}$ While Merkzeichen, or signs of perception, take place at a first person perspective, we might say that Wirkzeichen, or signs of action (i.e. of relating to others, or to something different from oneself), occur at a second person perspective.
} 
Notably, as Stjernfelt (2001: 96) remarks, a Categorical perception reading of Uexküll empowers Umwelt theory with an argument "against certain assumptions in the neo-Darwinist doxa, namely, the idea that all order in nature is the result of natural selection".

As a primitive order notion, [categorical perception] in its formal version seems to be a necessary prerequisite for life as such, rather than being a contingent feature of selection. Thus, it constitutes a germ of order which cannot be the result solely of natural selection. Rather, natural selection seems to presuppose [categorical perception] in order to have orderly alternatives from which to select.

Acknowledging that Uexküllian-style categorical perception - that is, the functioning of phenomenal categories, corresponding to the fundamental ways-of-life of beingsprovides the raw material or building stones of evolution, we get a clearer picture of in what way the emergence of new life forms depends, for a start, on two factors: constraints in the architecture of phenomena (mirroring constraints in biological architecture, and behavioural constraints), and what variations of life forms are, in any given ecological situation, already present. In order to establish an ontological niche, not only does a new species have to be endowed with a specific semiotic competence that enables it to encounter the various demands that its ecological counterparts are bound to set forth. It also has to establish at least one contrapuntal relation that is unique to it (which could be as simple as '[type of being] eating [type of being]') and that, along with the other relations it partakes in, defines it as a species. What evolves, from this perspective, just as much as the physical organism (or the genotype), is the way of life which is carried out by the being at hand, not least the way of relating to a certain selection of others - appearing, as it does, to the being itself, at a private level of subjectivity, as well as to others, at the level of observable behaviour.

\section{Uexküll and Phenomenology}

Partly due to Uexküll's usage and further development of Immanuel Kant's term Erscheinungswelt (phenomenal world), and his concept of a subjective biology as such, biosemiotics has always had a definite affinity with phenomenology, in modern times developed by Edmund Husserl (1859-1938). For biosemioticians, writes Jesper Hoffmeyer (2004: 89), there is "nothing mysterious about the phenomenal world, for it is deeply embedded in bodily semiotics". This contrasts with eliminativist materialist ontologists claiming that human (or non-human) experience is epiphenomenal on bodily activity (such as brain activity), thus leaving "the phenomenological world as a complete mystery. What is the good of it? Why is it there?" Uexküll's biological endeavor was to move, at least in its emphasis, from an effectual toward a perceptual perspective, or from an externalist to an internalist viewpoint, and was carried out by way of reworking the philosophical foundation of biology. As Søren Brier notes (2001: 779), "a true phenomenological theory of signification/semantics" was immanent in his conception. In Uexküll's account, the phenomenal world is not (though it envelops these) simply the domain of rationality, or human experience, as claimed by Kant, Hegel, Husserl and most contemporary phenomenologists, but rather, to borrow a phrase from contemporary eco- 
phenomenologist David Abram (1997: 19), an organic complex of "countless worlds within worlds that spin in the depths of this world that we commonly inhabit".

While admitting that Uexküll's 'protosemiotic' theory and his biophenomenological stance are intimately related, Andreas Roepstorff (2001: 755) claims that "his outline of what could perhaps be called a biological phenomenology is at least as important" as his explicitly semiotic contribution. Important, I would add-even for a proper understanding of his semiotic work. Coupling the animal subject and its environment figuratively in the functional cycle, where they form a closed loop of interactions, Uexküll, as Torsten Rütung writes (2004: 52-53), recognized that "embodied selfreference not only serves to control movements, but is a central prerequisite for a coherent perception of the world". This elementary finding provides biosemiotics with an invaluable key to a proper understanding of phenomenology, which can be said to have a biosemiotic foundation. Through its universal application (in the realm of life) of concepts such as subjectivity and intentionality, biosemiotics depicts a world of the living in which all living beings are to be regarded as true subjects actively engaged and involved in (and through) their life-worlds.

Uexküll's starting point in philosophy was Kant, but that doesn't make the Umwelt theory, in all its aspects, an expression of Kantianism. As Pobojewska phrases it (2001: 326), “Uexküll's axiom, despite its similarity to Kant's thesis, states: 'all reality is a phenomenon of living beings'." That is quite different from Kant's 'all reality is a phenomenon of the human mind'. While Kant established that reality has a phenomenological character, Uexküll added that this reality is not purely human, enveloping, as it does, a vast and diverse realm of phenomena of which but a fragment is exclusively human. Further, according to Uexküll, man is not pure mind, but a corporeal reality or an embodied mind, which is in its turn indistinguishable from the phenomenal world it carries with it, and without which its bodily performance would make no sense.

"Had [Husserl] survived to see our present predicament", Jane Howarth writes (2000: 53), referring to the contemporary ecological crisis, "he would doubtless have thought that the two crises were closely linked, the one he wrote of [a crisis in European thinking] being the root of the present one". Husserl's primordial finding was that science had become estranged from our direct human experience, and that scientific discourse had lost any direct relevance to the sensuous world of our everyday engagements. His concept of the human Lebenswelt, or life-world, resembles Uexküll's Umwelt concept (cf. Husserl 1954) - more so than Martin Heidegger's concept of the human Dasein (literally, 'there-being'), referring to the human condition as characterized, in crude terms, by concern and involvement in one's own life. ${ }^{10}$ Heidegger was acquainted with Uexküll's work, which he reviewed

\footnotetext{
${ }^{10}$ Anton Markoš, defining interpretation as a problem of understanding in his sketch of a hermeneutics of the living, curiously suggests (2002: 40) that "we should accept the task of seeking a status of Dasein for all living beings. [...] From the point of view of a biologist, I see the relation 'Dasein = any living being' as fully legitimate." Markoš believes that biosemiotics "can do much to solve the problem" of giving room for concepts of Dasein within biology. "From here," he claims (2002: 41), "a better understanding of phenomena such as adaptation, morphogenesis, evolution, and so forth, could emerge." Matching the hermeneutic circle with Uexküll's functional cycle, we could say that each act of interpretation (i.e., each roundtrip in the circle/cycle) informs, or renews, the contextual (flexible) component of the Bauplan, resulting in a never-ending process, carried out by the being in question, of a constantly updated, always already operable pre-understanding of any given ecological matter.
} 
as part of a series of biology lectures in 1929-30. And he did in fact grant animals a certain phenomenological subjectivity, though he held that 'the animal is poor in world', as opposed to man, which is world-forming (cf. Heidegger 1995). His assertion that only man knows things as things can be considered as a philosophical relative of Deely and Susan Petrilli's notion of man as a 'semiotic animal'.

Though it is still a marginal academic phenomenon, there have been attempts to develop an eco-phenomenology, or environmental phenomenology (cf. Brown and Toadvine (eds.) 2003; Tymieniecka (ed.) 2007). According to Benjamin Hale (2005: 103) the governing supposition of many aspiring eco-phenomenologists is "that a successful approach to environmental ethics requires a shift in thinking about ontology". It is a peculiar fact, however, that even proclaimed environmental phenomenologists mainly or exclusively reason from a human point of view. As a matter of methodology, in dealing with issues of ecology, that is not a promising start. The basic contribution of Uexküll's thought, as a possible foundation for ecophenomenology, is exactly the theoretically modeled perspective of each and every living being. If eco-phenomenology is to be considered-one day-as a mature philosophical enterprise, then it will have to concern itself not only with man's relation to nature, but moreover with nature itself. Only through such a path will it ultimately develop, and thrive, not only in its aspect of philosophical anthropology, but also as a true philosophy of nature (and how else will it be able to sort out man's relation to nature?).

David Abram, author of the modern classic The Spell of the Sensuous. Perception and Language in a More-Than-Human World (Abram 1997), is by far the one who has done the most to develop a philosophical doctrine worthy of the name ecophenomenology. He is vaguely familiar with Uexküll's work and the zoosemiotic writings of Thomas Sebeok, and sees a 'common project' in biosemiotics (personal correspondence), though he referred to neither of these in his main work. "It is my belief", he stated some 20 years ago (Abram 1988: 101), "that the phenomenological investigations of Maurice Merleau-Ponty provide the seeds of a new and radical philosophy of nature that remains true to the diversity of experience within the biosphere of this planet".

In Abram's development, Merleau-Ponty's embodied intersubjectivity becomes an ecological intercorporeality. Though Abram does-just as Heidegger, and, as we shall see, Merleau-Ponty - extend the phenomenological notion of subjectivity to (at least 'higher') animals, he does this by, in effect, dissolving the distinction between what is truly subjective and what only appears to be so. "To define another being as an inert or passive object", he correctly observes (1997: 56), "is to deny its ability to actively engage us and to provoke our senses; we thus block our perceptual reciprocity with that being". But then he goes on to claim that to the sensing body, nothing presents itself as utterly passive or inert. True enough, perhaps, but so what? 'To define another being' as either passive or active, we first need to be able to distinguish between beings and non-beings. Abram's stand on this point seems to be a consequence of his defence of the sensuous viewpoint of oral, indigenous cultures. Referring to Merleau-Ponty, he asserts (1997: 90) that "our spontaneous, preconceptual experience yields no evidence for a dualistic division between animate and 'inanimate' phenomena". Human experience, however, is not merely preconceptual, and any narrative displaying it as such risks missing out on species- 
defining aspects of human existence (cf. what I in Tønnessen 2003: 290 briefly refer to as 'conceptualized Umwelt experience'). From a semiotic point of view, we can safely conclude that perception is in some cases only apparently a reciprocal phenomenon, and that the animatedness or apparently dialogic nature of our surrounding landscapes is in some cases due to the animating power of the active perceiver.

Merleau-Ponty, for his part, related explicitly to Uexküll in his lectures in the late fifties, as reflected in the posthumously compiled work Nature, which has only fairly recently been translated into English (Merleau-Ponty 2003). The chapter 'Animality: The Study of Animal Behavior' is mostly devoted to the Umwelt theory. Referring to the fact that an 'Umwelt' in scientific terms is a model of an apparently existing phenomenal world, the French phenomenologist frames (2003: 167) an Umwelt as "an intermediary reality between the world such as it exists for an absolute observer and a purely subjective domain". "The Umwelt is never total", he writes (2003: 178) "we are englobed in an Umgebung that our Umwelt cannot englobe". Further (2003: 178), the "Umwelt is not presented in front of the animal like a goal; it is not present like an idea, but as a theme that haunts consciousness". Uexküll's Umwelt represents a mode of knowledge where "we no longer see where behavior begins and where mind ends".

\section{A Semiotics of Being}

As for the occurrence of phenomenal worlds, a modern Uexküllian phenomenology will hold that particular (private) phenomenal worlds occur throughout the sphere of life. Different as the worlds of plants and fungi might be, they nevertheless, having feedback cycles that connect sensors and regulators, vaguely resemble the worlds of other beings, be they unicellular or multicellular. Acknowledging that plants and fungi, as well, perform categorical perception, operating with perceptual categories (though these might be of an indexical rather than iconic nature), it might be a matter of semantic taste whether or not we label these phenomenal worlds as 'Umwelten'.

We should be cautious, however, about what the concept of a 'phenomenal world' is taken to signify in the context of biosemiotics - not least since it is originally an anthropocentric and consciousness-oriented conception. One example at hand, illustrating a certain confusion, is Jesper Hoffmeyer, who has explicitly agreed to "broaden the Umwelt concept to cover the phenomenal worlds of plants, fungi, and protists" (2001: 396), and yet seems to equate the term 'experienced world' with the Umwelten of higher animals. In his article on 'Uexküllian Planmässigkeit' (Hoffmeyer 2004), he claims (2004: 93) that "the experienced world is a tool for solving non-routine problems, or, in general, for dealing with events which could not be foreseen". Not so. What is a phenomenal world, if not an experienced world? "Lacking movement as part of their survival tool kit", Hoffmeyer claims (same page), "plants most likely never developed experiential worlds, whereas a graded series of such worlds may well occur as glimpses of awareness throughout the animal kingdom". While his denial of (or disbelief in) any experiential aspect of 'lower' phenomenal worlds calls for disapproval, Hoffmeyer more interestingly describes (2004: 91-92) how higher animals, allegedly placed between the indexicality of plants and the symbolicity of men, possess "an experienced holistic virtual reality, an internal icon more or less isomorphic in its properties with those 
parts of the real world that the animal could not safely ignore". Only this "iconic inner experience', according to Hoffmeyer, predominant among mammals and birds, display "constructed virtual items behaving very much like things and creatures outside of the head". ${ }^{11}$

Much debate has tagged along with the fundamental, yet not unproblematic biosemiotic notion that (here in the words of Sebeok 2001: 68) "because there can be no semiosis without interpretability - surely life's cardinal propensity-semiosis presupposes the axiomatic identity of the semiosphere with the biosphere". Partly related to this, there is a spectre of understandings of what an 'Umwelt' - interpreted in various fashions as a 'specific universe', a 'cognitive map', a 'model world', an 'existential realm' and so on (cf. Salthe 2001: 365) -really represents. In the following I will attempt to demonstrate that an 'Umwelt', whatever else it might be taken to be, necessarily refers to an underlying experienced world, to the effect that the Umwelt carrier (the phenomenal subject) must be said to be endowed with awareness, defined as the appearance of semiosis at a first/second person perspective. $^{12}$

Frederik Stjernfelt (2001: 84-85) is among those who claim that Uexküll's method "takes its departure in objective, spatial qualities characterizing behavior and consequently does not imply anything about the subjective what-is-it-like-to-be-a-bat experiences". ${ }^{13}$ While it is true that Uexküll himself explicitly declared neutrality as to the assumptions of the 'Tierpsychologie' (animal psychology) of his period, it is at the same time evident that at many points of his work he in fact does assume the existence of experienced worlds. Today, we should be in a position to consider the assumption of underlying experienced worlds as an integrated part of the Umwelt concept. In a biosemiotic, or modern Uexküllian sense, I dare to claim, concepts of 'perception' as well as of 'action' are rendered meaningless without the assertion that what our third-perspective Umwelten attempt to model is experienced worlds which are themselves subjective, private models of the semantic landscape (so to speak) that surrounds Umwelt carriers. Devoid of this initial semiotic perspective, we would be left with a world where living beings only act as if they were active, autonomous subjects. If biosemiotics were to adopt Uexküll's functional models, only to stay neutral with regard to, or-slightly worse-deny any true first person subjectivity in the world of the living, little would have been won by applying Umwelt theory at all. The notions of 'subjectivity', 'autonomy' etc. only retain their true meaning given the metaphysical assumption that they ultimately refer to an existential realm.

\footnotetext{
${ }^{11}$ One is tempted, however, faced with such a head-centeredness, to ask in what way our understanding of an 'icon', or 'similarity', is relative to our perceptual, human constitution, since it appears to be so obvious to us that only we, and creatures like us, see objects 'the way they are'.

12 Cf. footnote 9.

${ }^{13}$ Noteworthy, Thomas Nagel (1993) in his article 'What is it like to be a bat?' takes it for granted that there is a way in which it is to be a bat-in other words, that a bat-like subjectivity do correspond to what we can (imperfectly) observe as bat behaviour. The intriguing question for Nagel is how this bat experience would appear to us, if we could experience it from a first person perspective. Naturally, we can not, and Nagel's whole article dwells around the ontologically momentous difference between the third person perspective of science and the first person perspective of actual beings. For a treatment of Nagel's thought and its relevance for Umwelt theory and biosemiotics, see Tønnessen 2001: 687-690.
} 
As Anton Markoš remarks (2002: 29), life "proceeds synchronously on innumerable space, time, and organizational levels. Nothing on any single level can reveal its essence". Nevertheless, a neglect of the individual-which for numerous life forms constitute the principal level of being (qua experiencing, acting etc.) - would result in a rude kind of biology. This is the rationale for adhering to an integrated biological individualism, as described earlier in this text. Thomas Sebeok claimed (2001: 72) that assertions that biosemiotics has evolved from the study of animal communication to more general considerations of biological codes "simplifies, even skews, an, in truth, far more labyrinthian sequence of events culminating in biosemiotics to which zoosemiotics is but one contributing factor". Be that as it may - at any rate, there are certain tendencies within biosemiotics - no doubt mirroring macro-tendencies within mainstream biology - which threaten to reduce the biosemiotic enterprise to a mere semiotics of functioning, rather than, also, a semiotics of being.

The properties at risk here are what we could call, with a general term, 'inner states' (cf. Stjernfelt 2001: 98). In analogy with notions such as 'mental state' and 'cognitive state', I suggest to use the term semiotic state. While in philosophy of mind a 'mental state' refers to a certain performance which is unique to rational or sentient beings, a 'semiotic state' is to be understood as the state of a sign process, an inner state (in its most general form) which might be said to be distinctive not only for all living beings, but for all living systems, as far as they possess what we could call semiotic integrity, defined as an autonomous (self-organized) coordination of semiosis. Reiterating the definition of an Umwelt transition, we can state that environmental change, in a biosemiotic sense, is a lasting, systematic change, within the life cycle of a body of semiosis (any living system displaying semiotic integrity, whether or not it is a being proper), from one semiotic state characteristic for its being to another.

Phenomenology in its anthropocentric or consciousness-centric version "maintains that all mental states are directed" (cf. Howarth 2000: 57). An Uexküllian phenomenology is equipped to broaden the field of study considerably by maintaining that all semiotic states are directed. All semiotic states, put plainly, are about something, they refer to and involve certain objects of semiosis that are treated according to a certain agenda. Intentionality, accordingly, is not as such a characteristic of the mental, but rather of the semiotic - to which, of course, the mental belongs.

A 'state' should here be taken to signify the condition, situation or-spatially considered - position of a body of semiosis; being 'stationary' only in the sense of constituting, or sustaining, an inner or integral contextualization of and for its sign process - as opposed to outer, or external contextualizations, through which a body of semiosis is positioned vis-à-vis other bodies of semiosis. A semiotic state, in other words, is the self-referential form which a sign system assumes in order to realize a certain agenda. Semiotic states are temporal; always mediating between the (effectual, and/or perceptual) agenda of a body of semiosis and the possibilities of the moment as these are manifested in the sign process itself, thus situating and conditioning the body of semiosis from within. Semiotic states are further, as mentioned, intentional in the sense that they are aimed at realizing an intention, in accordance with an agenda. As my mentor Kalevi Kull has suggested to me, the 
most general semiotic state, in which all life dwells and attempts to continue to dwell, might be the state of being alive itself.

As for the ontological status of phenomena and semiosis, I gladly support Stjernfelt's rejection (2001: 96) of radical constructivism, to the effect that an Umwelt must be understood to take place "in a common world which is not in itself a construction". The so-called material world - though thoroughly reconceptualisedcan in other words be incorporated into an Uexküllian conception of reality. ${ }^{14}$ As Salthe points out (2001: 375), in a sense "Uexküll is a realist because counterstructures [i.e., whatever lies 'behind' the Umwelt objects] are taken to deliver true signs (even if symbolic) of objects in the environment". It is this, according to Salthe, which enables creatures with an Umwelt to learn and be adaptable. I furthermore acknowledge a notion of 'semiotic realism', stating, in one way or another, that appearances are no less 'real' than hard matter.

The unveiling of 'reality', however, must be considered an endless (and in most aspects private) process. As David Abram (1997: 112) brilliantly narrates in The Spell of the Sensuous, referring to the cultural transition from oral to alphabetic culture, "the literate self cannot help but feel its own transcendence and timelessness relative to the fleeting world of corporeal experience". The adoption of a literate culture, in short, most likely fundamentally transformed our perception of the land. "At the moment when we make this world become the object of scientific cognition”, as Pobojewska (2001: 327-328) writes in her explanation of the Umwelt theory, "we become the second grade observers". This statement curiously echoes Merleau-Ponty's appeal (1962: viii-ix) that "we must begin by reawakening the basic experience of the world, of which science is the second-order expression". By defining the human body as the subject of awareness, Abram remarks (1997: 47), Merleau-Ponty "demolishes any hope that philosophy might eventually provide a complete picture of reality (for any such total account of "what is" requires a mind or consciousness that stands somehow outside of existence". And such it is with Uexküll as well.

\section{References}

Abram, D. (1988). Merleau-Ponty and the voice of the earth. Environmental Ethics, 10, 101-120.

Abram, D. (1997). The spell of the sensuous. Perception and language in a more-than-human world. New York: Vintage Books.

Brier, S. (2001). Cybersemiotics and Umweltlehre. Semiotica, 134(1/4), 779-814.

Brown, C. S. \& Toadvine, T. (Eds.) (2003). Eco-phenomenology: back to the earth itself. Albany: State University of New York Press.

Deely, J. (2001). Umwelt. Semiotica, 134(1/4), 125-135.

Fraser, J. T. (2001). The extended Umwelt principle: Uexküll and the nature of time. Semiotica, 134(1/4), $263-273$.

\footnotetext{
${ }^{14}$ Cf. especially von Uexküll 1956: 100-101 - the grand finale of Streifzüge-where Uexküll alludes to 'die Umwelten der Naturforscher' (the Umwelten of scientists). "Here, as well," Uexküll declares at one point, "we get a glimpse of a real world which displays a fragment of reality" ("Auch hier blicken wir in eine wirkliche Welt, die einen kleinen Ausschnitt der Natur wiedergibt."
} 
Hale, B. (2005). Experience and the environment: phenomenology returns to earth. Book Review. Human Studies, 28, 101-106.

Heidegger, M. (1995). The fundamental concepts of metaphysics: world, finitude, solitude. Bloomington: Indiana University Press.

Hoffmeyer, J. (1996). Signs of meaning in the universe. Bloomington: Indiana University Press.

Hoffmeyer, J. (2001). Seeing virtuality in nature. Semiotica, 134(1/4), 381-398.

Hoffmeyer, J. (2004). Uexküllian Planmässigkeit. Sign Systems Studies, 31(1/2), 73-97.

Howarth, J. (2000). Phenomenology and the environment. In V. Pratt, J. Howarth, \& E. Brady (Eds.), Environment and philosophy (pp. 53-80). London/New York: Routledge.

Husserl, E. (1954). Die Krisis der europaischen Wissenschaften und die Tranzendentale Phänomenologie (Husserliana: Gesammelte Werke 6). Haag: Martin Nijhoff.

Hutchinson, G. E. (1978). An introduction to population ecology. New Haven, Connecticut: Yale University Press.

Kauffman, S. A. (2000). Investigations. Oxford: Oxford University Press.

Kremer, M. (1993). Population growth and technical change, one million B.C. to 1990. Quarterly Journal of Economics: $681-716$.

Kull, K. (1998). Semiotic ecology: Different natures in the semiosphere. Sign Systems Studies, 26, 344-371.

Kull, K. (2004). Uexküll and the post-modern evolutionism. Sign Systems Studies, 32(1/2), 99-114.

Leakey, R., \& Lewin, R. (1996). The sixth extinction. Patterns of life and the future of humankind. New York: Anchor Books.

Lorenz, K. (1973). Die Rückseite des Spiegels. München: Pieper.

Lovelock, J. (2006). The revenge of Gaia. Why the earth is fighting back-and how we can still save humanity. Allen Lane/Penguin.

Markoš, A. (2002). Readers of the book of life. Contextualizing developmental evolutionary biology. New York: Oxford University Press.

Merleau-Ponty, M. (1962). Phenomenology of perception. Translated by Colin Smith. London: Routledge \& Kegan Paul.

Merleau-Ponty, M. (2003). Nature. Compiled by Dominique Séglard, translated by Robert Vallier. Evanston, Illinois: Northwestern University Press.

Nagel, T. (1993). Mortal questions. Cambridge: Cambridge University Press.

Nöth, W. (1996). Ökosemiotik. Zeitschrift für Semiotik, 18(1), 7-18.

Nöth, W. (1998). Ecosemiotics. Sign Systems Studies, 26, 332-343.

Pobojewska, A. (2001). New biology_Jakob von Uexküll's Umweltlehre. Semiotica, 134(1/4), 323-339.

Roepstorff, A. (2001). Brains in scanners: An Umwelt of cognitive neuroscience. Semiotica, 134(1/4), 747-765.

Rütung, T. (2004). History and significance of Jakob von Uexküll and of his institute in Hamburg. Sign Systems Studies, 31(1/2), 35-72.

Salthe, S. (2001). Theoretical biology as an anticipatory text: The relevance of Uexküll to current issues in evolutionary systems. Semiotica, 134(1/4), 359-380.

Sarkar, S. (2005). Biodiversity and environmental philosophy. An introduction. Cambridge: Cambridge University Press.

Sebeok, T. A. (2001). Biosemiotics: Its roots, proliferation, and prospects. Semiotica, 134(1/4), 61-78.

Stjernfelt, F. (2001). A natural symphony? To what extent is Uexküll's Bedeutungslehre actual for the semiotics of our time? Semiotica, 134(1/4), 79-102.

Tønnessen, M. (2001). Outline of an Uexküllian bio-ontology. Sign Systems Studies, 29(2), 683-691.

Tønnessen, M. (2003). Umwelt ethics. Sign Systems Studies, 31(1), 281-299.

Tymieniecka, A.-T. (Ed.) (2007). Phenomenology of life from the animal soul to the human mind. In search of experience. Analecta Husserliana-The Yearbook of Phenomenological Research vol. XCIII.

von Uexküll, J. (1909). Umwelt und Innenwelt der Tiere. Berlin: Verlag von Julius Springer.

von Uexküll, J. (1921). Umwelt und Innenwelt der Tiere (2nd ed.). Berlin: Verlag von Julius Springer.

von Uexküll, J. (1922). Wie sehen wir die Natur und wie sieht sie uns? Die Naturwissenschaften, 12, 265271 296-301, 316-322.

von Uexküll, J. (1928). Theoretische biologie. Second edition. Berlin: Verlag von Julius Springer.

von Uexküll, J. (1931). Die Rolle des Subjekts in der Biologie. Die Naturwissenschaften, 19(19), 385391.

von Uexküll, J. (1956). Streifzüge durch die Umwelten von Tieren und Menschen: Ein Bilderbuch unsichtbarer Welten. Bedeutungslehre. Hamburg: Rowohlt.

von Uexküll, J. (2001). The new concept of Umwelt: A link between science and the humanities. Translated by Gosta Brunow. Semiotica, 134(1/4), 111-123. 